\title{
PEMBERDAYAAN KADER KESEHATAN DALAM MENGKAJI SELF-CARE PADA PASIEN HIPERTENSI
}

DOI: https://doi.org/10.33024/jkpm.v4i4.3996

\author{
Eka Afrima Sari ${ }^{1^{*}}$, Ristina Mirwanti ${ }^{2}$, Yusshy Kurnia Herliani ${ }^{3}$ \\ 1,2,3 Fakultas Keperawatan, Universitas Padjadjaran \\ Disubmit: 10 Maret 2021 Diterima: 17 April 2021 Diterbitkan: 04 Agustus 2021
}

Email: e.afrima@unpad.ac.id

\begin{abstract}
ABSTRAK
Hipertensi merupakan merupakan penyakit kronis yang dapat dikendalikan salah satunya dengan perawatan diri (self-care). Sehingga diharapkan dengan self-care akan meningkatkan derajat kesehatan dan kualitas hidup. Untuk mencapai keberhasilan dalam mengendalikan hipertensi, diperlukan keterlibatan unsur masyarakat, salah satunya kader kesehatan. Kader kesehatan dapat berperan serta dalam mendampingi dan men-support pasien hipertensi dalam self-care hipertensi. Namun, belum ada program yang secara khusus melatih kader kesehatan dalam mengkaji self-care hipertensi. Sehingga program pengabdian masyarakat yang berorientasi pada pemberdayaan kader kesehatan dalam selfcare hipertensi diperlukan guna mencegah komplikasi dan meningkatkan kualitas hidup pasien hipertensi. Kegiatan ini bertujuan meningkatkan pengetahuan kader dalam mengkaji self-care pada pasien hipertensi. Metode kegiatan berupa pendidikan masyarakat yaitu pelatihan kader kesehatan dalam mengkaji selfcare pasien hipertensi. Target dan sasaran pada kegiatan ini adalah kader kesehatan di wilayah kerja Puskesmas Pasundan Kota Bandung sebanyak 37 orang. Luaran kegiatan ini adalah peningkatan pengetahuan kader dalam mengkaji self-care pada pasien hipertensi. Evaluasi dilaksanakan dengan mengukur pengetahuan kader kesehatan sebelum dan setelah dilakukan pelatihan. Hasil kegiatan didapatkan bahwa terdapat perbedaan pengetahuan (a 0.000) setelah mengikuti pelatihan. Kegiatan pengabdian pada masyarakat berupa pelatihan kader kesehatan dalam mengkaji self-care hipertensi ini efektif dalam meningkatkan pengetahuan kader kesehatan mengenai hipertensi dan self-care hipertensi.
\end{abstract}

Kata Kunci: Hipertensi, Kader Kesehatan, Self-Care

\begin{abstract}
Hypertesion is a chronic disease which can be controlled by self-care. It is hoped that self-care will improve the health and quality of life. To achieve success in controlling hypertension, it is necessary to involve one element of the community (health cadre). Health cadres can participate in assisting and supporting hypertensive patients in self-care hypertension. However, there is no program that specifically trains health cadres in assessing hypertension selfcare. So that community service programs oriented to empowering health cadres in hypertension self-care are needed to prevent complications and improve the
\end{abstract}


quality of life for hypertensive patients. The purpose of this activity is to increase health cadre knowledge in assessing self-care in hypertensive patients. The method of activity is training of health cadres in assessing self-care for hypertensive patients. The target of this activity was 37 health cadres in the work area of Pasundan Health Center in Bandung City. Outcome of activities is an increase in cadre knowledge in assessing self-care in hypertensive patients. Evaluation is seen from the knowledge of health cadres before and after training. The result of the activity was that there were differences in knowledge of health cadres (a 0.000) after attenting the training. Health cadre training in assessing hypertension self-care is effective in increasing health cadres' knowledge about hypertension and hypertension self-care.

Keywords: Health Cadres, Hypertension, Self-Care

\section{PENDAHULUAN}

Hipertensi merupakan salah satu penyebab kematian nomor satu di dunia (Hartzell, Avis, Lozano, \& Feig, 2016; Kementerian Kesehatan Republik Indonesia [Kemenkes RI], 2014). Dari 65.048.110 jiwa (25,8\%) prevalensi hipertensi di Indonesia, sebanyak 13.612 .359 jiwa $(29,4 \%)$ berasal dari provinsi Jawa Barat (Riset Kesehatan Dasar [Riskesdas], 2013; Kemenkes RI, 2014). Hipertensi juga merupakan salah satu penyakit terbanyak di puskesmas Kota Bandung pada tahun 2014 (Profil Kesehatan Kota Bandung 2014, 2015).

Hipertensi merupakan masalah yang serius dan mengalami peningkatan setiap tahunnya dengan diikuti peningkatan komplikasi, baik akut maupun kronis. Sehingga diperlukan pengendalian yang baik untuk mencegah tejadinya komplikasi akut dan mengurangi risiko komplikasi dalam jangka panjang. Untuk mengendalikan hipertensi diperlukan perawatan diri (selfcare). Self-care merupakan kemampuan individu, keluarga, dan masyarakat untuk berpartisipasi dalam promosi dan perlindungan kesehatan, pencegahan penyakit, dan penanganan penyakit serta kecacatan baik dengan atau tanpa dukungan dari penyedia layanan kesehatan (Webber, Guo, Mann, 2013). Penelitian yang dilakukan oleh Sari, Afriandi, Sari (2017) pada lansia di Kota Bandung menunjukkan bahwa tekanan darah sistolik lansia berada pada mean 157,54 dan tekanan darah diastolik berada pada mean 93,24. Lansia tersebut ada yang sedang dalam proses pengobatan hipertensi, ada yang baru mengetahui kalau memiliki tekanan darah tinggi, adapula yang sedang dalam proses pengobatan namun tidak teratur datang ke layanan kesehatan. Hal ini menunjukkan belum terlaksananya perilaku self-care hipertensi, sehingga penting untuk dilakukan pemantauan self-care pasien hipertensi yang merupakan salah satu faktor dalam pengendalian penyakit hipertensi.

Untuk mencapai keberhasilan dalam mengendalikan hipertensi, diperlukan keterlibatan unsur masyarakat, salah satunya kader kesehatan. Kader kesehatan dapat berperan serta dalam mendampingi dan men-support pasien hipertensi dalam self-care hipertensi.

Belum adanya program yang secara khusus melatih kader kesehatan dalam mengkaji self-care hipertensi serta banyaknya jumlah pasien hipertensi yang masih memiliki tekanan darah dalam kategori hipertensi derajat II $(84,7 \%)$ dan berat badan dalam kategori obesitas $(54,2 \%)$ di wilayah kerja Puskesmas Pasundan Kota Bandung (Sari, Mirwanti, dan Herliani, 
2018), menunjukan bahwa pelaksanaan self-care pasien hipertensi belum optimal. Sehingga program pengabdian pada masyarakat yang berorientasi pada pemberdayaan kader kesehatan dalam mengkaji self-care hipertensi diperlukan guna mencegah komplikasi hipertensi sehingga dapat meningkatkan kualitas hidup pasien.

Kegiatan pengabdian pada masyarakat yang bertujuan ikut serta memecahkan permasalahan kesehatan yang ada di masyarakat ini merupakan media yang sangat tepat dalam memfasilitasi kader kesehatan guna meningkatkan pemahaman mengenai self-care hipertensi sehingga dapat berperan serta dalam mendukung pasien dengan hipertensi dalam meningkatkan kualitas hidupnya. Dengan adanya kegiatan pengabdian pada masyarakat ini, diharapkan kader kesehatan mampu memberikan kontribusi dalam mencegah komplikasi jangka panjang pasien dengan hipertensi sehingga dapat meningkatkan kualitas hidup pasien dalam mencapai derajat kesehatan yang optimal.

\section{MASALAH}

Hipertensi merupakan salah satu penyakit terbanyak yang ditemukan di puskesmas Kota Bandung. Wilayah kerja Puskesmas Pasundan memiliki kader kesehatan yang berperan serta dalam pengendalian hipertensi. Salah satu peran kader ini adalah memberikan support dalam pengontrolan tekanan darah. Namun pemahaman kader hanya terbatas pada pengontrolan tekanan darah, sedangkan pemahaman kader mengeni self-care pada pasien hipertensi secara menyeluruh masih sangat minim. Kegiatan pengabdian pada masyarakat ini bertujuan untuk meningkatkan pengetahuan kader mengenai self-care pada pasien hipertensi. Lokasi kegiatan pengabdian pada masyarakat, dapat dilihat pada Gambar 2.1 dibawah ini.

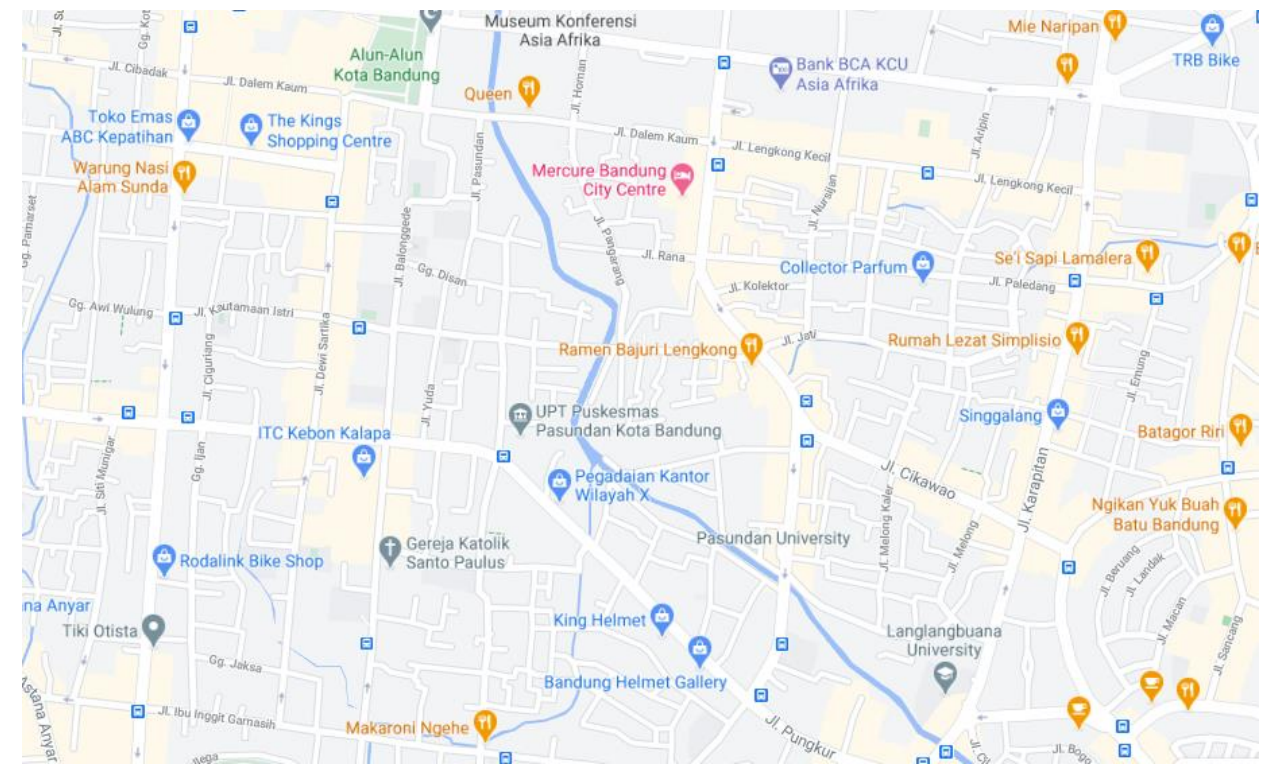

Gambar 2.1 Peta Lokasi Kegiatan Pengabdian Pada Masyarakat 


\section{METODE}

Kegiatan pengabdian pada masyarakat ini berupa pelatihan kader kesehatan dalam mengkaji self-care hipertensi. Kegiatan pengabdian pada masyarakat ini dilakukan di Aula Puskesmas Pasundan Kota Bandung. Khalayak sasaran pada kegiatan ini adalah kader kesehatan di wilayah kerja Puskesmas Pasundan Kota Bandung yang berjumlah 37 orang.

Kegiatan ini menggunakan metoda ceramah, diskusi, dan evaluasi. Sebelum mulai pelatihan kader kesehatan diberikan pre test mengenai pengetahuan terkait hipertensi dan self-care hipertensi. Kemudian diberikan materi pelatihan mengenai hipertensi, cara mengkaji self-care hipertensi, dan peran kader dalam meningkatkan self-care hipertensi. Setelah pemberian materi dilakukan evaluasi berupa post test mengenai pengetahuan terkait hipertensi dan self-care hipertensi.

Tingkat pengetahuan kader dianalisis berdasarkan skor yang diperoleh oleh kader saat pre test maupun post test, kemudian dibagi menjadi tiga kategori, yaitu baik, cukup, dan kurang. Setelah diperoleh nilai pre test dan post test, kemudian dilihat apakah terdapat perbedaan skor pengetahuan kader sebelum dan setelah dilakukan kegiatan pelatihan.

\section{HASIL DAN PEMBAHASAN}

Kegiatan Pengabdian pada Pada Masyarakat ini dimulai dengan perizinan pelaksanaan kegiatan ke Puskemas Pasundan Kota Bandung untuk melakukan kegiatan pelatihan kepada kader kesehatan di wilayah kerja Puskesmas Pasundan Kota Bandung. Setelah mendapatkan izin kegiatan, dilakukan sosialisasi dan koordinasi dengan perawat penanggung jawab germas dan koordinator kader kesehatan untuk waktu pelaksanaan kegiatan. Kemudian tim menyiapkan materi pelatihan, media pelatihan, dan instrumen evaluasi kegiatan. Setelah semua persiapan dilakukan, dilakukan kegiatan pelatihan dengan dihadiri oleh kader kesehatan dan petugas puskesmas.

Kader yang terlibat dalam kegiatan pelatihan ini seluruhnya berjenis kelamin perempuan dengan pendidikan rata-rata sekolah menengah atas (SMA), bekerja sebagai ibu rumah tangga, sebagian kecil memiliki riwayat hipertensi dan riwayat keluarga dengan hipertensi, rata-rata berusia 50 tahun, dan rata-rata telah menjadi kader selama 11 tahun.

Sebelum kegiatan pelatihan, kader kesehatan diberikan pre test mengenai hipertensi dan self-care hipertensi. Didapatkan hasil pre test bahwa kader dengan pengetahuan baik sebanyak 28 orang $(75,68 \%)$ dan pengetahuan cukup sebanyak 9 orang (24,32\%). Kegiatan pre test dapat dilihat pada Gambar 4.1 dibawah ini.

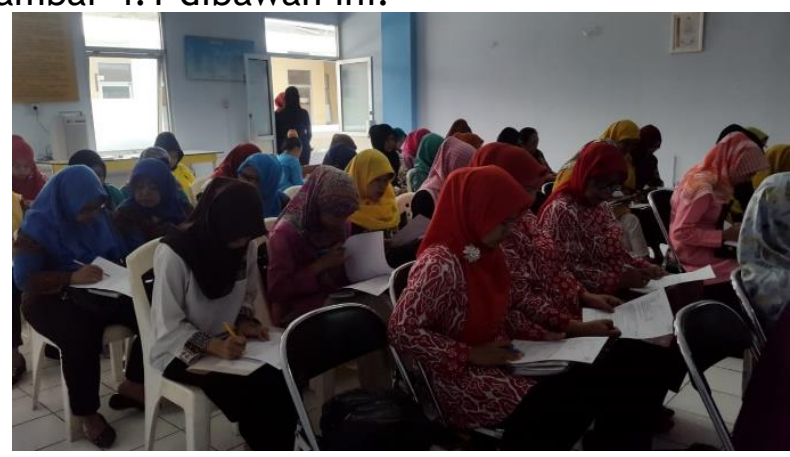

Gambar 4.1. Kegiatan Pre Test 
Kegiatan dilanjutkan dengan pemberian materi pelatihan mengenai hipertensi, cara mengkaji self-care hipertensi, dan peran kader dalam meningkatkan self-care hipertensi yang dilakukan oleh tiga orang dosen dari Fakultas Keperawatan Universitas Padjadjaran. Pada saat pemberian materi, kader kesehatan terlihat sangat antusias, hal ini juga terlihat pada saat sesi tanya jawab, hampir sebagian besar kader kesehatan aktif bertanya. Kegiatan pemberian materi pelatihan dapat dilihat pada Gambar 4.2 dibawah ini.

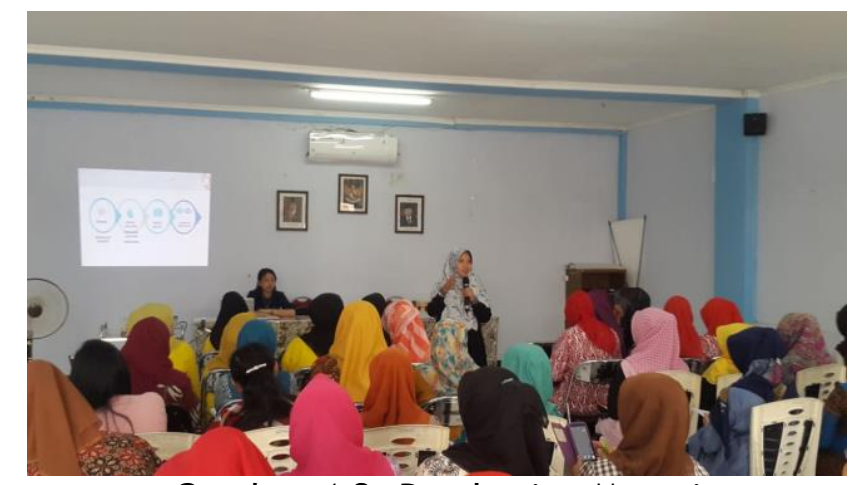

Gambar 4.2. Pemberian Materi

Setelah pemberian materi, dilakukan evaluasi melalui post test kepada kader kesehatan. Didapatkan hasil bahwa seluruh kader memiliki pengetahuan baik (100\%). Hasil pre test dan post test pengetahuan kader mengenai hipertensi dan self-care hipertensi dapat dilihat pada Gambar 4.3 dibawah ini.

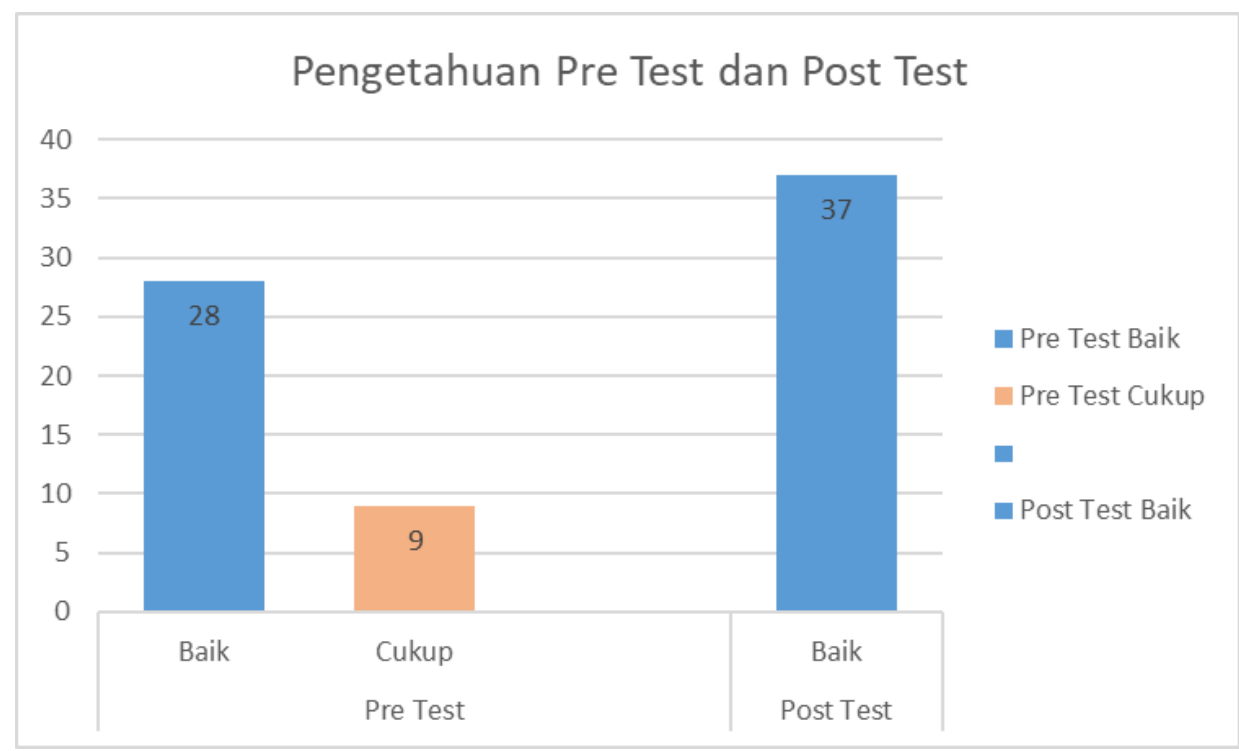

Gambar 4.3. Pengetahuan Kader Sebelum dan Setelah Pelatihan

Hasil perbedaan rata-rata pengetahuan kader kesehatan sebelum dan setelah pelatihan dapat dilihat pada Tabel 4.1 dibawah ini. 
Tabel 4.1. Hasil Uji Perbedaan Rata-Rata Pengetahuan Kader Sebelum dan Setelah Pelatihan

\begin{tabular}{rllll}
\hline Variabel & $\begin{array}{l}\text { Sebelum } \\
(\text { M(SD) }\end{array}$ & $\begin{array}{l}\text { Setela } \\
\mathbf{h} \\
\mathbf{M}(\mathrm{SD})\end{array}$ & $\mathbf{Z}$ & $\mathbf{P}$ \\
\hline Pengetahuan & 10,08 & $\begin{array}{l}11,00 \\
(0,71)\end{array}$ & $-3,57$ & 0,000 \\
& $(1,09)$ & & \\
\hline
\end{tabular}

Hasil evaluasi terhadap pengetahuan kader kesehatan mengenai hipertensi dan self-care hipertensi, didapatkan perbedaan pengetahuan kader kesehatan sebelum dan setelah kegiatan pelatihan dilakukan (a 0.000). Hal ini menunjukkan bahwa kegiatan pelatihan ini efektif dalam meningkatkan pengetahuan kader kesehatan. Sejalan dengan penelitian yang dilakukan oleh Fasya, Pratama, Mandala, Nurmalasari, \& Pebrian (2021) yang menyatakan bahwa terdapat peningkatan pengetahuan setelah dilakukan penyuluhan. Domain yang sangat penting dalam menentukan terbentuknya perilaku seseorang adalah pengetahuan. Perilaku yang positif dipengaruhi oleh pengetahuan yang positif, pun sebaliknya (Notoatmodjo, 2012).

Dengan meningkatnya pengetahuan kader kesehatan mengenai selfcare hipertensi ini, diharapkan dapat memberikan kontribusi dalam mendampingi dan men-support pasien hipertensi dalam melaksanakan selfcare sehingga hasil akhir yang diharapkan adalah tidak terjadinya komplikasi dan meningkatnya kualitas hidup pasien hipertensi. Sesuai dengan Camphell (2014) yang menyatakan bahwa upaya pemberdayaan masyarakat (kader) akan mempengaruhi gaya hidup pasien hipertensi dan penelitian yang dilakukan oleh Fulton, Schelffler, Sparkes, Auh, Vujicic, \& Soucat (2011) yang menunjukkan bahwa peningkatan peran kader dapat meningkatkan pelayanan kesehatan.

\section{KESIMPULAN}

Kegiatan pengabdian pada masyarakat berupa pelatihan kader kesehatan dalam mengkaji self-care hipertensi ini efektif dalam meningkatkan pengetahuan kader kesehatan mengenai hipertensi dan selfcare hipertensi. Saran dari kegiatan ini adalah perlu adanya monitoring yang dilakukan oleh perawat mengenai pelaksanaan self-care pada pasien hipertensi.

\section{DAFTAR PUSTAKA}

Camphell, E.S. (2014). Empowerment as A Management Strategy in Hypertesive African American Women. European Journal of Research in Social Sciences, 2 (1).

Fasya, H., Pratama, S.A., Mandala, Z., Nurmalasari, Y., Pebrian, U. (2021). Penyuluhan tentang Protokol Kesehatan Covid-19 pada Masyarakat di Puskesmas Sumur Batu Teluk Utara Bandar Lampung. Jurnal Kreativitas Pengabdian Kepada Masyarakat (PKM), 4(1), 195-199.

Fulton, B.D., Schelffler, R.M., Sparkes, S.P., Auh, E.Y., Vujicic, M., \& Soucat, A. (2011). Health Workforce Skill Mix and Task Shifting in Low 
Income Countiries: A Review of Recent Evidence. Hum Resour Health. Jan 11; 9(1):1. DOI: 10.1186/1478-4491-9-1.

Hartzell, K., Avis, K., Lozano, D., \& Feig, D. (2016). Obstructive Sleep Apnea and Periodic Limb Movement Disorder in a Population of Children with Hypertension and/or Nocturnal Nondipping Blood Pressures. Journal of the American Society of Hypertension, 10(2), 101-107. https://doi.org/10.1016/j.jash.2015.11.010.

Kemenkes. (2014). Infodatin Jantung. Infodatin, 109 (Jantung), 5-10. https://doi.org/10.1017/CBO9781107415324.004.

Kemenkes RI. (2014). Pusdatin Hipertensi. Infodatin, (Hipertensi), 1-7. https://doi.org/10.1177/109019817400200403.

Notoatmodjo, S. (2012). Promosi Kesehatan dan Perilaku Kesehatan. Jakarta: PT. Rineka Cipta.

Riskesdas. (2013). Badan Penelitian dan Pengembangan Kesehatan. Laporan Nasional 2013, 1-384. https://doi.org/1 Desember 2013.

Sari, E.A., Mirwanti, R., Herliani, Y.K. (2018). Karakteristik dan Pengetahuan Pasien dengan Hipertensi di Wilayah Kerja Puskesmas Pasundan Kota Bandung. Prosiding Seminar Nasional dan Workshop Keperawatan. Fakultas Keperawatan Universitas Padjadjaran Bandung 14-15 November 2018.

Sari, S.P., Afriandi, I., Sari, E.A. (2017). Identifikasi angka kejadian serta faktor-faktor yang berhubungan dengan kejadian luka tekan pada lansia di rumah. Unpublished.

Webber D, Guo Z, Mann S. (2013). Self-Care in Health: We Can Define it But Should We Also Measure it. Self Care, 4(5),101-5. 